Section Editor

Mitchell S.V. Elkind, MD, MS

Bao-Hui Hung, MD Chia-Ling Chiang, MD Po-Ching Wang, MD Ping-Hong Lai, MD

Address correspondence and reprint requests to Dr. Ping-Hong Lai, Faculty of National YangMing University School of Medicine, Department of Radiology, Veterans General Hospital-Kaohsiung, 386 TaChung First Rd., Kaohsiung, 813, Taiwan, ROC phlai@isca.vghks.gov.tw

\title{
Teaching NeuroImages: Terminal myelocystocele
}

\section{Figure 1 Sonography}

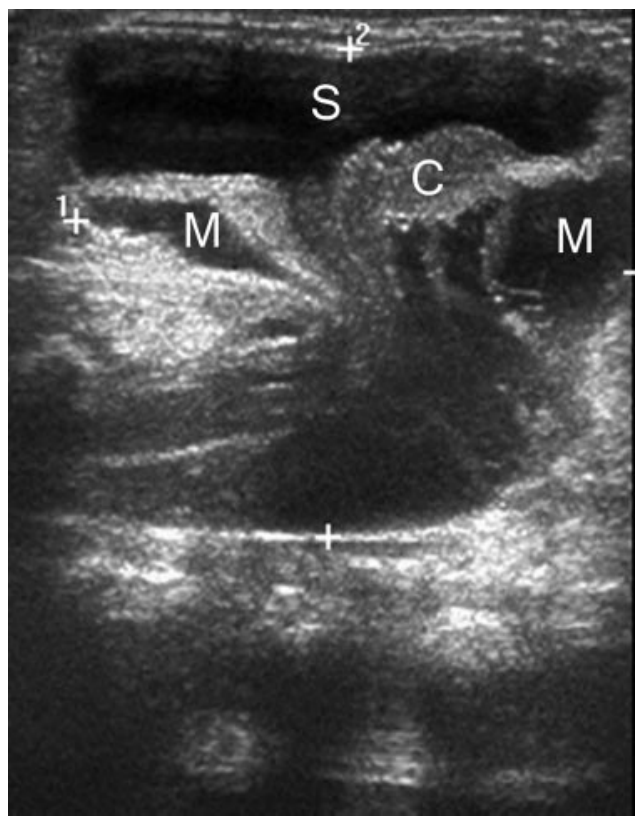

Sonography of the sacral area shows a trumpetlike flaring syringocele (S) and surrounding meningoceles (M) with a deformed and displaced spinal cord (C).

A 1-day-old boy presented with a protruding nontender soft mass $(8 \times 7 \mathrm{~cm})$ in the posterior sacral area at birth, with intact overlying skin. Sonography revealed a cystic dilation of the distal central canal surrounded by dilated subarachnoid space (figure 1). MRI confirmed the diagnosis of terminal myelocystocele by the typical finding of a
Figure 2 MRI

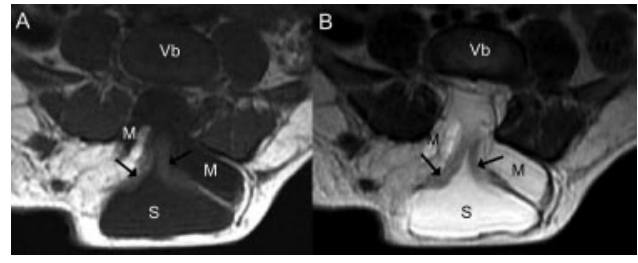

Axial T1-weighted (A) and T2-weighted (B) MRI scans show a similar depiction as sonography. Arrows point to the deformed and displaced spinal cord. $\mathrm{M}=$ meningocele; $\mathrm{S}=$ syringocele; $\mathrm{Vb}=$ vertebral body.

trumpetlike flaring syringocele and meningoceles (figure 2).

Terminal myelocystocele, a rare form of occult spinal dysraphisms, is characterized by hydromyelic dilation of the distal central canal (syringocele), bulging through a posterior spina bifida and surrounded by an expanded dural sheath (meningocele). ${ }^{1}$ Even though uncommon, it should be included in differential diagnosis of congenital sacral mass. Although ultrasound is an excellent initial screening modality, MRI is necessary to confirm the diagnosis and delineate the anatomy. ${ }^{2}$

\section{REFERENCES}

1. Rossi A, Cama A, Piatelli G, Ravegnani M, Biancheri R, Tortori-Donati P. Spinal dysraphism: MR imaging rationale. J Neuroradiol 2004;31:3-24.

2. Unsinn KM, Geley T, Freund MC, Gassner I. US of the spinal cord in newborns: spectrum of normal findings, variants, congenital anomalies, and acquired diseases. Radiographics 2000;20:923-938. 


\title{
Neurology
}

\author{
Teaching NeuroImages: Terminal myelocystocele \\ Bao-Hui Hung, Chia-Ling Chiang, Po-Ching Wang, et al. \\ Neurology 2011;76;e72 \\ DOI 10.1212/WNL.0b013e318214358d
}

\section{This information is current as of April 4, 2011}

\section{Updated Information \& Services}

\section{References}

\section{Subspecialty Collections}

Permissions \& Licensing

\section{Reprints}

including high resolution figures, can be found at: http://n.neurology.org/content/76/14/e72.full

This article cites 2 articles, 0 of which you can access for free at: http://n.neurology.org/content/76/14/e72.full\#ref-list-1

This article, along with others on similar topics, appears in the following collection(s):

\section{All Pediatric}

http://n.neurology.org/cgi/collection/all_pediatric

All Spinal Cord

http://n.neurology.org/cgi/collection/all_spinal_cord

MRI

http://n.neurology.org/cgi/collection/mri

Neonatal

http://n.neurology.org/cgi/collection/neonatal

Ultrasound

http://n.neurology.org/cgi/collection/ultrasound

Information about reproducing this article in parts (figures,tables) or in its entirety can be found online at:

http://www.neurology.org/about/about_the_journal\#permissions

Information about ordering reprints can be found online:

http://n.neurology.org/subscribers/advertise

Neurology ${ }^{\circledR}$ is the official journal of the American Academy of Neurology. Published continuously since 1951, it is now a weekly with 48 issues per year. Copyright Copyright $@ 2011$ by AAN Enterprises, Inc.. All rights reserved. Print ISSN: 0028-3878. Online ISSN: 1526-632X.

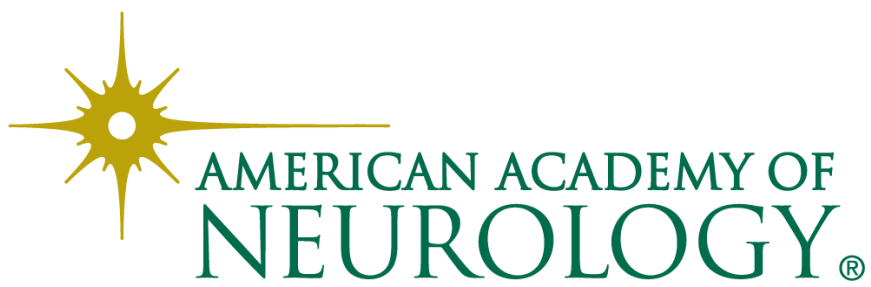

